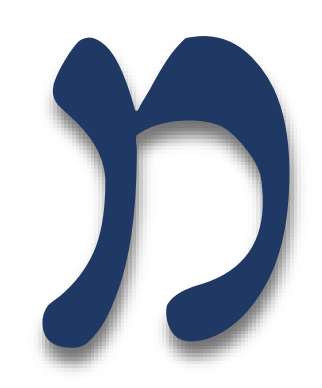

\title{
Memories of Salonica: \\ Estrea Aelion celebrates her one hundredth birthday
}

\author{
Recuerdos de Salónica: Estrea Aelion celebra sus cien años
}

\author{
Hilary Pomeroy \\ University College London, United Kingdom \\ hilarypomeroy@aol.com \\ ORCID: 0000-0003-4902-8699
}

Cómo citar este trabajo I How to cite this paper

Pomeroy, Hilary. (2020). Memories of Salonica: Estrea Aelion celebrates her one hundredth birthday. Meldar: Revista internacional de estudios sefardíes, 1, 75-89. https://doi.org/10.46661/meldar.5387

\begin{abstract}
Estrea Aelion was born in Salonica in 1884. She belonged to a well-off family; her grandfather opened Salonica's first department store and her father was a jeweller. In 1994, she celebrated her hundredth birthday in London and dictated her memories for her family and, especially, for her great grandchildren. Estrea Aelion lived at the beginning of a period of great change for Salonica and the Jewish community. Her memories are not a formal historical document, they are personal experiences. She was one of the first girls to go to school, in her case a missionary one, although her brothers went to an Alliance Israélite Universelle school. She witnessed the arrival of modern inventions such as electricity and running water. She lived through the catastrophic 1890 and 1917 fires. Estrea Aelion's memories, however personal they may be, are a document of great interest to all those interested in a vanished world.
\end{abstract}

Key words: Female education; missionary schools; marriage; fires; modernisation.

\section{Resumen}

Estrea Aelion nació en Salónica en 1884. Perteneció a una familia acomodada: su abuelo abrió el primer gran almacén de Salónica y su padre fue joyero. En 1994 Estrea Aelion celebró sus 100 años en Londres y escribió sus memorias para su familia, sobre todo para sus bisnietos. Estrea Aelion vivió al comienzo de una época de cambio enorme para la ciudad y para la comunidad judía. Sus recuerdos no constituyen un documento histórico formal, sino unas experiencias personales. Fue una de las primeras chicas en ir a la escuela, en su caso a una escuela de la Misión Protestante, aunque sus hermanos cursaran sus estudios en una escuela de la Alliance Israélite Universelle. Fue testigo de la llegada de invenciones modernas tales como la electricidad y el agua corriente. Vivió los incendios catastróficos de 1890 y 1917. Los recuerdos de Estrea Aelion, por más personales que sean, forman un documento de suma importancia para todos los que se interesen en un mundo desaparecido.

Palabras clave: Educación femenina; escuelas misioneras; matrimonio; incendios; modernización. 


\section{Memories of Salonica: Estrea Aelion's Centenary Account}

"Ag-ora con el ayudo del Dio, asperamos el anniversario de mis 100 anios al 5 Mayo" (C, 6). In May 1984 members of the Aelion family gathered in London to celebrate with Nona Aelion her one hundredth birthday. Among the guests was her granddaughter, Andree Brooks, who arrived from New York for a two-week stay. With Andree Book's encouragement, Estrea Aelion began to dictate memories of her life in Salonica, Istanbul, Paris and London to be presented as a jubilee present to her family. As her mastery of English was not sufficient for this purpose and the family had only a limited understanding of Ladino, Mrs. Aelion dictated her account in French. This was duly translated into English (version A). The second of the three tapes, dealing with life during the First World War, was accidentally erased and so there is a hiatus in the narration. Encouraged by this venture, Mrs. Aelion then wrote out those memories in Ladino, her native language (version B). The manuscript consists of nineteen unlined margin-less pages measuring 215 centimetres by 280 with the writing covering the entire page. Estrea's son, Leon Saltiel, typed this out (version C) plus an additional English version (D). There is a further copy of A in the Wiener Holocaust Library as members of the Aelion family perished in the Holocaust. ${ }^{1}$

This vivid recollection of Estrea Aelion's early life in Salonica is not just a precious family memento but provides a wonderful resource for the study of life in Salonica's Jewish community at the turn of the twentieth century. This was an era without telephone or e-mail when messages were sent between households by a trusted servant or messenger. Trams were drawn by horses along the sea front until the arrival of the, at first frightening, electric-powered trams. Estrea's childhood was spent in a city where a substantial portion of the population was Jewish, and it was still very much the 'Jerusalem of the Balkans'. Estrea mentions such major events as the 1912-1913 Balkan Wars and the devastating 1917 fire but these are perceived as an inevitable part of life in Salonica and are not analysed. Like Leon Sciaky's memoir, Farewell to Salonica, it is a "personal, not a political or historical work" (Barnett, 1974: 2) ranging from uncritical glimpses of historical events to details of everyday family life.

\section{HistORICAL EVENTS}

Estrea Aelion lived in Salonica from 1884 until 1920 and was witness to events of extraordinary historical and political importance. She speaks of the good relations between

1 I am very grateful to members of the Aelion family, especially her granddaughter Andrée Aelion Brooks and her great granddaughter Sara Solnick, for their encouragement and support in this project. I would also like to thank Leah Bornstein-Makovetsky, Gila Hadar, Rena Molho, Margaret Sleeman and Susana Weich-Shahak for their insights. 
Jews and Turks: "Half the town was Jewish, and they got on well with the Turks because the Turks liked them very much. [...] And they were all happy very happy" (A, 2). However, after the Greek army entered the city and Salonica was annexed to Greece in 1912 "the Greeks did not get along so well with the Jews [...]. They were forced to open on Saturdays and close on Sundays. And people started to emigrate" (A, 17-18). Prior to this

[...] the Jews dominated commerce and trade. They closed on Saturdays, and as the Jews closed on Saturdays, the whole town closed because nothing could be done. The banks were closed, the customs house was closed, the shops, the big Jewish shops were closed. Ships that came could not unload because everything was in Jewish hands (A, 2).

When Mrs. Aelion's Italian uncle, David Errera, decided to leave for Milan he suggested that the Aelion family live in the family villa in Las Campagnas. The town was soon full of soldiers of the Allied Armies and the Italian consul asked David Errera to open a shop providing provisions for the armies, the "Magasino Italiano". This was run by Mrs. Aelion's husband, Saltiel, and her brother $(\mathrm{A}, 18)$.

Estrea Aelion lived through two major fires, including the "Great Fire" of 1890: "On September 4, 1890, the poorer and the most crowded streets in the northwest and west of Salonica fell pray [sic] to flames that destroyed 2,000 houses, most of them shacks inhabited by Jews" (Molho, 2005: 108). ${ }^{2}$ She describes the devastating 1917 fire:

We couldn't put the fire out because the town's water was cut -12 hours, half to the civilians and half for the soldiers. So the water was turned off and there was none to put the fire out. We asked the armies to let the water run so we could put out the fire. And they replied 'the water is for the soldiers'. The fire took on enormous proportions - in 24 hours, the entire Jewish quarter in Salonika was burned, the shops, and even other quarters well. We didn't know where to go $(\mathrm{A}, 18-19){ }^{3}$

As the Aelion family was now living in Las Campagnas, their garden became a place of shelter:

[...] people slept in the streets just like that. They started moving to the countryside; the countryside hadn't been affected, thank God, because the fire stopped at the White Tower. At our house, many people came - there was a big garden and people sat out there on the ground all night. Until the day when the maids started making coffee and making things a little easier. In the meantime, the electricity and gas stations were closed and we had no gas or electricity, we used charcoal instead to live $(\mathrm{A}, 19) .{ }^{4}$

\footnotetext{
2 For a study of two poems in Ladino describing the fire, see Romero (2008: 329-344).

3 “[...] el general francés Maurice Serrail, comandante en jefe de las fuerzas Aliadas, no autorizó el uso del agua que tenían almacenada las tropas" (Romero, 2008: 649).

4 See Romero (2008: 650-661).
} 
The Aelion family left Salonica after the First World War, living first in Istanbul and then Paris before finally settling in London in 1937.

\section{THE AELION FAMILY}

Estrea Aelion came from a well-off family. Her father, Jacob Matalon, was a "jolliero, vindia cosas de oro i de plata i sovre todo perlas finas" $(C, 1) .{ }^{5}$ As the daughter of a pearl merchant, Estrea would have been accustomed to an affluent life style and, as granddaughter Andree Brooks remarked to me, her hands were those of a woman who had never done any manual work.

Estrea's paternal grandparents were Italian. Guedalia Errera owned one of the biggest shops in Salonica. Estrea referred to this as a department store and compared it with the Galeries Lafayette. ${ }^{6}$ He imported goods from all over Europe, sold "yarn, lace, house things, kitchen things, everything" (A, 2) and also manufactured goods in Salonica.

\section{THE FAMILY HOME}

Estrea Aelion's family belonged to the prosperous bourgeoisie. Her grandfather, Guedalia Errera, built a villa at 25 Avenida Reina Olga in Las Campagnas (Gk. Exoches), an area of expensive villas and summer houses. His two sons, who both worked in the family business, also lived there together with their families, each occupying a different floor. Estrea recalled "a beautiful villa on the outskirts of Salonica. [...] In front of it there was the most magnificent garden. He [grandfather Errera] also had a very large garden at the back, with greenhouses where they grew the most exotic flowers" (D, 2). According to Estrea Aelion's niece, Beatrice Barzilay, "Our house was very large and spacious with surrounding gardens. I can say that we led a luxurious lifestyle". ${ }^{7}$ This was a world apart from the cramped, insalubrious conditions experienced by the majority of Salonica's Jewish

5 I quote here Leon Saltiel's transcription of Mrs. Aelion's handwritten Ladino version (B) retaining the idiosyncratic spelling of the original. Estrea Aelion undertook this task at the age of one hundred and presumably used the hand-writing style and spelling she had learnt as a child at the missionary school.

6 Mrs. Aelion lived in Paris from 1923 to 1935 and frequented Parisian department stores. She enjoyed going for tea at Galeries Lafayette and Printemps (A, 26).

7 From Beatrice Barzilay's submission of names to the Holocaust Martyrs and Heroes' Remembrance Authority, Yad Vashem, Jerusalem (no date). Beatrice and her mother Caroline Matalon moved from Salonica to Athens in 1943. Beatrice was sheltered from the Germans by George and Polymnia Theodorakis, thus escaping deportation. Several members of the Aelion family died in the camps. The family house in Salonica was burned down. On 12 April 2011 Giorgios and Poly Theodorakis were named "Righteous Among the Nations" by Yad Vashem. 
population, the working class. According to the British ethnologist Lucy Garnett who spent several years researching various ethnic communities and women's customs and culture in the Balkans:

In places where the Jews form large communities, their quarter is almost as overcrowded as a London slum, many families among the very poor occupying one house. [...] Indeed, some of the Salonica streets were often, in the summer simply impassable, so poisonous was the atmosphere, owing to the accumulations of refuse of every description thrown into them from the neighbouring houses (1891: 4-5).

Garnett relates several of the incidents that Estrea Aelion lived through, thus corroborating the latter's accounts.

Mrs. Aelion immediate family lived together in one house, as was the norm, probably in the centre of Salonica: "On one floor there was my father, my family and on the floor above, there was his brother, he had four girls and four boys" $(\mathrm{A}, 9)$.

As Mark Mazower has commented:

Poverty had always plagued the Jews in particular; the 1835 census reveals a far higher proportion of Jews coming from poor households than anyone else [...]. Towards the end of the century it was clear that despite the impressive wealth of a few, the vast majority of Jews lived in great poverty. More than twenty thousand of the poorest of them were rendered homeless by the fire of 1890 (Mazower, 2004: 251).

The frequent fires that devastated so much of Salonica do not seem to have affected Estrea's family although she mentions, in passing, an earthquake: “There was an earthquake once in Salonika, I was quite grown-up then. Everyone was scared because it lasted nearly a week. No-one dared go into the house to get anything. I was very brave and would go into the house to make coffee, take it outside to my parents" $(\mathrm{A}, 6)$.

\section{FEMALE EdUCATION}

Following the establishment of the Alliance Israélite Universelle in 1860, its network of schools grew rapidly. In Salonica the first Alliance school for boys opened in 1873 and a vocational girls' school in 1887: "until then most women did not receive any schooling and were mainly occupied by sewing, knitting and carpet weaving at home" (Molho 1993: 265). Estrea's brothers went to unspecified Jewish schools where "the headmasters had come from Paris" (A, 4). These were presumably Alliance Israélite Universelle schools' as Alliance staff were trained in Paris. 
Garnett (1891: 18) commented that "Female education among the Jews of Turkey owes the little advance it has made, during the past twenty years or so, rather to the efforts of foreign members of the community", a statement supported by Estrea: "The Germans opened schools, the French opened schools, the Italians opened schools [...] And then the Israelis above all, had the colonial alliance" (A, 4). Unlike her brothers, Estrea was not sent to a Jewish school but to a missionary establishment. It was run by Scottish Protestants, the Reverend Peter Crosbie and his wife, although Estrea refers to the couple as English (A, 5).

For Leah Bornstein-Makovetsky, author of a comprehensive study of missionary schools in the Balkans:

[...] the establishment of schools for Jewish girls by the missionaries was an important innovation for the Jews. Women's education in these schools made Jewish women more aware of the need for schooling and vocational training, and eventually contributed to the creation of Jewish schools for girls (2019: 26).

\section{Estrea writes:}

It was a very good school. Mr. Crosbie spoke very good Spanish, Hebrew, judaismo, Rashi, everything. And all the Jewish girls were given lessons on the Bible. Jewish girls were taught the Old Testament. And girls who were not Jewish, Mrs. [unintelligible] taught them the New Testament $(A, 5)$.

The girls were also taught French and needlework.

The Crosbies' school was attended by pupils from varied backgrounds. The Crosbies did not charge girls from straightened circumstances and Estrea comments on their charitable deeds. They "used to bring second-hand clothes from England and distribute them to the needy girls" $(B, 1)$. One pupil, Reyna Cohen came from a very poor home. She used her schooling to great effect, publishing three books and various political essays at in the late-nineteenth and early-twentieth centuries. ${ }^{8}$ Although well-liked by the Jewish community, Reverend Crosbie did not succeed in converting any pupils: "avian venido a Salonique esperando de convertir a los djidios a la religion Protestante, Ma asto no creyo qua reucheron, ma se fisieon grandes amigos con la population djudia de Salonique, i erarn muy estimados" $(C, 1)$. The Crosbies' school was eventually taken over by the Alliance Israélite Universelle. ${ }^{9}$

Despite having had a home tutor for a while, Estrea's mother never learned to read or write (A, 7). Like so many women of her generation, her aspirations for her daughter's future were practical rather than academic: 'And my mother asked "what do you need to

8 See Hadar (2015: 149-166), Bornstein-Mazovetzky (2019: 219-223).

9 Molho (1993: 266). 
learn English for? Who are you going to speak English to? [...] No, you're not going to learn, it's not necessary - you're going to learn how to sew for yourself, for the house, and then you're going to sew your trousseau for when you get married"' $(A, 6)$. Ironically, this refusal prevented Estrea from communicating with her granddaughters when, decades later, she moved to London.

Preparation of a girl's trousseau began in early childhood. In addition to clothing, it would contain embroidered towels and bedding including sheets, quilts and pillows. ${ }^{10}$ Needle skills were so highly valued at this time that grandmother Errera gave Estrea the Singer sewing machine that accompanied Estrea throughout her life and which is still in the family:

La Nona de Errera me merko ouna maquina de cousir venia la impregada del magasin ondé merko la maquina para me ambezar a la empleyar esta maquina andé me iva mela iévava con mi i la tengo in Londra la maquina tiene 85 agnos é cousé al tanto boeno como el primer dia que la tengo $(B, 5)$.

Practical skills such as sewing were an important part of the curriculum at the Alliance girls' schools as demonstrated in this letter from a teacher at the Izmir school: "The trades for which the girls are trained are dressmaking, laundering, needlework, lacemaking, millinery, and pressing" (Rodrigue, 1993: 95). In Estrea's case this skill would be put to use in preparing her trousseau but in that of girls from impoverished families it would provide a vital supplement to the family income. ${ }^{11}$

As Estrea's mother remained illiterate, she would wait every Friday for her daughter to read an instalment of whichever novel appeared in the Ladino newspaper, La Época, ${ }^{12}$ here Le comte de Monte Cristo by Alexandre Dumas:

Apart from all the news it reported, it published part of a story. It was the story of Montecristo, to start with. So my mother would wait for the newspaper to arrive, because she couldn't read, and she would sit next to me so I could read her the chapter of the story. And every Friday evening was the same thing until the story ended. Then another story would begin $(\mathrm{A}, 7){ }^{13}$

This must have been a common scene in many Sephardi households and clearly illustrates the differences between the generations brought about by modern education.

10 For the importance of textiles and embroidery in Sephardi communities, see Juhasz (1990).

11 As an example of this, in the late-nineteenth century and early-twentieth century many of the workers in the tobacco industry, one of Salonica's main industries, were women. See Hadar $(2006,2007)$, Mazower (2004: 388-339).

12 See Gaon (1965: 19, no. 20).

13 See Romero (1992: 222, 227, 248). 
Journals were often shared and read aloud to groups of women just as it had been a common practice for parts of the Me'am Lo'ez, usually the week's bible portion, to be read aloud to groups of women on Shabbat. It became standard practice for the Judeo-Spanish press to publish instalments of novels on a weekly basis. These were usually translations or adaptations of foreign novels and, for the most part, French. ${ }^{14}$

\section{WOMEN'S LIVES}

Estrea's memoir is not an academic record of life in Salonica in the late-nineteenth century. It is simply a personal souvenir intended to familiarise her family with the life she had known. Like Leon Sciaky's Farewell to Salonica in which Sciaky "describes life as he experienced it" (Barnett, 1974: 2), Estrea recounts but does not analyse. Unlike the majority of Salonica's Jewish community for whom financial hardship, even extreme poverty, was a reality, Estrea Aelion came from a prosperous bourgeois family. The memoir focuses on her daily life which, as was typical of Sephardi women, centred on the home and family: "At that time, women stayed at home to look after the family" (A, 3), "that time" presumably referring to her youth. Girls learnt how to run the family home and follow specific religious observances by copying their mother: "Until the formal religious education of women in the late nineteenth century as part of the women's educational movement, most women learned only the domestic aspects of Judaism" (Dorn Sezgin 2005: 222). This was not, however, the case in the Aelion home where, unusually, Jacob Matalon gave Estrea the occasional Hebrew lesson and: "Once a week he would bring all the children together and recite the prayer that would be sung on Saturday and the story that would be told, and I was treated like a boy in my family" (A, 6). She even surprised Mr. Crosbie because, on two occasions, she already knew the Bible lesson he was teaching (5).

According to Estrea:

[...] girls were not sent to school! [...] But they knew everything perfectly - all the prayers, they knew them perfectly, everything, everything. That's why they sang all the time. And the children heard the old songs, from the time when they arrived from Spain, from mother to daughter, they all knew songs and we didn't stop singing all day long (A, 4). ${ }^{15}$

Estrea Aelion did not forget the songs she had learnt in her childhood, probably as lullabies, and continued to sing until an advanced age. ${ }^{16}$ In 1982, now almost one hundred

14 According to Bürki the Judeo-Spanish press "was a powerful means of distributing works belonging to the new imported literary genres: the novel and the drama" (2010: 104). See also Romero (1992: 179).

15 For a general study of Salonica's ballad tradition see Pomeroy (1999). There are detailed studies of Salonican ballads in Armistead \& Silverman $(1971,1979)$ and Pomeroy $(2002,2008)$.

16 The singing of ballads to accompany difference stages of the life cycle is discussed in Pomeroy (2002). 
years old, she was interviewed by the academic researcher, Margaret Sleeman. In all, Dr. Sleeman collected thirty-five ballads, which Mrs. Aelion referred to as cantigas rather than romansas, and these were to form the central core of Sleeman's doctoral thesis. Despite her long stay in London, Estrea had never fully mastered English and her excellent recall of the ballads she had learnt so long ago may possibly have been, not only because of the ballads' compelling stories, but because of her lack of contact with English culture. Samuel G. Armistead and Joseph H. Silverman noted a similar case during their field work in Van Nuys, California, in 1957. Their informant, Ester Varsano Hassid, a native of Salonica, had arrived in the United States in 1916: “[...] solo sabia leer el ladino; los caracteres latinos quedaban fuera de su alcance. Durante más de cuarenta años se había quedado al margen de la cultura americana. Era costurera de profesión y solía acompañar sus tareas con el canto de romances" (Armistead \& Silverman, 1979: 116). ${ }^{17}$

\section{PERSONAL FINANCE}

As the daughter of a jeweller and pearl merchant, Estrea inherited pearl necklaces which she later gave to her family, including her great granddaughters in England: "mi padré mos desho moutchas cosas alos ijos, mos deco moutchas perlas" $(B, 15) .{ }^{18}$ Pearl necklaces were a distinctive part of the Salonican Jewess's wardrobe and would become an essential part of her dowry: "The Salonikan yadrán was of special significance since it was both an essential part of the traditional costume and a status symbol" (Russo-Katz, 1990: 188). As Nicholas Stavroulakis (1988: 19) has commented "Jewellery, especially pearls were very popular with Salonika women, and every occasion was taken to wear them". ${ }^{19}$

Estrea Aelion recounts: “In Salonika, when I got married, women didn't have a bank account. When they married, the father gave the dowry to the husband and it was he who had responsibility for the family" (A, 27). However, as David Bunis has related, some women kept a number of coins aside for personal use, securing it on their person in "little knots" as a private banking system:

Many a mother and grandmother of old withdrew from those knots on their bodies enough money to marry off two or three daughters in a row. And not just this; those little lots on their flesh served the family well on dark days when 'Honoured Father' having fallen ill or failed in business had no money left (1999: 254-255).

\footnotetext{
17 Dr. Sleeman is currently preparing a revised and extended version of her doctoral thesis.

18 "Desho", "deco". One of the many examples of inconsistent orthography in the memoir.

19 See also Garnett (1891: 14-15).
} 
In the Salonica of Estrea's youth women had been dependent on family income in order to marry: "Money had to be given for a girl to marry. If there was no money, no dowry, no trousseau, she couldn't marry" (A, 15). Having settled in Paris, where she lived from 1923-1936, Estrea Aelion adapted well to Western life and its modern ways. The financial independence that women enjoyed appealed to her as in Salonica there had been no financial security: "Women had nothing of their own. The husband had everything [...]. At that time, when girls were married and their fathers died, they weren't left anything in the inheritance because they'd been given a dowry" (A, 29). In Paris she kept her pearls, as well as gold saved from her housekeeping, in a safe deposit box in a bank: "When I got to England, I took the gold with me and it was put in the bank for me" (A, 27). This was Mrs. Aelion's introduction to banking.

On one of her return visits to Salonica she chose to discuss her mother's financial situation with her father. He had only planned to include Estrea and her brothers in his will and not her mother, "What does she need?" (A, 29), but Estrea persuaded him to change his will and include her mother thus guaranteeing the latter's future financial security.

\section{Life CyCLE CUSTOMS}

Estrea Aelion commented on a case of polygamy, a little-known practice allowed under certain circumstances and a custom which had attracted Lucy Garnett's attention: “The Oriental Jews do not recognise the law of monogamy [...]. As a rule, however, they are practically monogamists, being allowed to take a second wife without divorcing the first for two reasons only - namely, the fact of the latter being childless, or the mother of girls only" (1891: 12). Mrs. Aelion describes the case of a married man who had no children and so his wife chose a second wife for him: "So he married her and she had 3 girls and 2 boys. His first wife treated them as her grandchildren" (33). This must have been a welcome outcome as sons were particularly favoured. They would earn a living, keep the family name alive and say the mourner's prayer, kaddish, after the man's death. ${ }^{20}$

One of the reasons for the popularity of songs, especially ballads (romansas), in the Jewish household is that specific texts accompanied different stages of the life cycle, from birth to death. However, the Sephardi song tradition did not include any specific lullabies. Instead, songs, especially ballads in which a birth took place, would be sung during the final stages of pregnancy and again after a birth, serving both as lullabies and cradle songs. ${ }^{21}$ The most popular songs were those accompanying birth or marriage.

\footnotetext{
20 See Pomeroy (2002: 65).

21 See Pomeroy (2002) for discussion of life cycle songs associated with Salonica.
} 
In her memoir, Estrea Aelion describes a poignant custom associated with old age. It was not unusual for an elderly person to decide to leave Salonica or elsewhere in the Balkans to settle and die in the land of Israel. ${ }^{22}$

[...] coando io touvé 18 agnos mi Nona de Errera detsidio que queria irse a Jerusalem. porqué queria mourirsé a ierouchalim in tierra santa. el dia que iva partir, el ijo grande i sou moujer la iva a acompagnar a ieruchalim i tanbien se estava ievando que ellia ouna moujer, para que la mirara in que le touviera compagnillia. toda la famillia i amigas nos foemos in ouna barka grandé a acompagnarla fina el vapor $(B, 6) .{ }^{23}$

She quotes the song Irme quero madre a Yerushalayim, a song of yearning for the homeland, commonly sung during the opening stage of the journey, "a work frequently cited by informants and well-known to all Jewish communities of the Balkans" (Refael, 2002: 216):

i estonses impesamos todas a cantarlé esta cantiga para mi Nona: llir me quero madré a yerouchalain, comer de aquellia tierra, comer i afartarmé: la notsé anothesé i el dia amanasé, miro de 4 partes por andé esclaresé: a yerouchalaim, la vello de infrinté, me parese madré, la louna in cresienté $(\mathrm{B}, 6){ }^{24}$

The song also served as an endecha or mourning song and was sung on Tishe $b^{\prime} A v$ in commemoration of the destruction of the Temple. Paloma Díaz-Mas (1994: 83-84) calls the song La nostalgia de Jerusalén y la restauración del templo, thus combining its two themes of yearning for Jerusalem and longing for the Temple to be restored. Estrea adds that Nona Errera's mother had died in Jerusalem and people were not sad to say goodbye in this way: "it was the tradition" (A, 12).

\section{MODERNISATION}

Estrea witnessed the early stages of modernisation in Salonica. Hitherto, drinking water had not been available in the home, only water for domestic use from wells or springs: "there was a person who came every day to bring us drinking water" (A, 8). Running water for the home was eventually introduced: "Civilisation meant running water piped to the home by the Compagnie des Eaux de Salonique rather than longer waits in the open air around communal wells and springs" (Mazower, 2004: 247). For Estrea "it was a wonder to open the tap and have water at home" $(\mathrm{A}, 8)$. Estrea explained to her grandchildren that until the arrival of electricity and gas, the family used charcoal for cooking and heating. As

22 See Garnett (1891: 35, 37-38).

23 Here, as in the citation below, there is inconsistent spelling of Jerusalem.

24 See Weich-Shahak (2012: 55, 293-295). See also Bunis (1999: 247-248) for the experiences and frequent hardship of Salonican Jews who made the journey to Israel. 
there was no refrigeration, surplus fruit was made into conserves to be stored away for winter. Transport was by horse-drawn trams: "There were no automobiles at that time but bit by bit, it changed. Electricity came, gas came, we had everything. [...] I wasn't easily scared but I couldn't understand how the tram could work without horses" (A, 9).

Like their Muslim counterparts, Jewish women stayed at home and so "to run errands we always had someone because women didn't go to the market in those days [...]. So the greengrocers would come to the front door" (A, 9) as did the milkman and the baker. It was the husband who would visit the marketplace to do the household shopping. When Estrea moved to Paris in 1923 she was shocked to find that this fell to her: "what was difficult for me to begin with was, I was told I had to go and do the food shopping myself. I found that strange, because in Salonika I was used to not buying anything, my husband bought everything" (A, 26).

Until after the First World War it was customary to use the services of a messenger to communicate with family and friends: "[...] when one was well off, one had a man who carried messages to family members. [...] And that's how we did it, there was no other way" $(\mathrm{A}, 9)$. Yacob Abraham Yoná was such a figure:

And as he walked, he would be reading or checking a list of the Jewish families in Salonika. His occupation was what the Sephardic Jews called combibador, that is, an individual who went from house to house with a list of guests to invite the occupants to a wedding or circumcision. [...] The combibador or combibadera, in Salonika, was familiar with all the local gossip. And so, when he was given a list of guests, he was told to invite so-and-so, who was known by such-and-such a nickname, appropriate to his reputation, etc. The poor combibador had to seek out the houses of all the guests on the basis of the vaguest orientations. (Armistead \& Silverman, 1971, 6-7)..$^{25}$

\section{CONCLUSION}

Estrea Aelion's reminiscences were intended as a personal souvenir for her family and, especially, her grandchildren and great grandchildren. It was only on a whim that Andree Brooks suggested, on the eve of the centenary celebrations, that Mrs. Aelion recount her life. The resulting memoir recalls a world very unfamiliar to her descendants and Mrs. Aelion pointed out the many ways life in Salonica had been changed by the advent of modernisation and the seismic changes brought about by national and international politics and conflict. Mrs. Aelion was brought up in material comfort in a loving extended family headed by the patriarch, Jacob Matalon. Her early life was spent in an almost enchanted world regulated by long-established personal and communal traditions. She, also, had the

25 For more imformation on Yoná, see Sefardiweb (http://www.proyectos.cchs.csic.es/sefardiweb/node/222) and Armistead \& Silverman (1971: 3-9). 
good fortune to be among the first generation of Sephardi women to experience female education.

Mrs. Aelion described the simple pleasures of her childhood, gathering together with friends to listen to stories for "there was always someone who knew how to tell good stories" (A, 7). As she grew up, Estrea Aelion experienced the gradual arrival of modernisation. She lived through two of the major catastrophes that befell Salonica and its Jewish community, the catastrophic fires of 1890 and 1917 with the subsequent loss of life, homes and synagogues from which the Jewish community did not fully recover.

A modest, unassuming woman, much loved by her family and clearly very much loved by all, Estrea Aelion had the mental capacity to adapt to and accept change:

Everyone thinks that I think about the old days and find modern life ridiculous. I have always adapted to each day and all the changes that go with that. It doesn't surprise me that, where once girls weren't allowed out on their own, now they are, they leave home altogether $[\ldots]$. And you have to adapt - when the world changes, everything has to change. (A, 33).

Throughout her life she had "faith in God. He's a person's best friend" (A, 34). Above all, Estrea Aelion was a true "eshet hayil", a woman of valour, whose attitude to life is concisely summed up in her own words: "Do gracias al Dio que me topo en buena saloud para fiestar con toda mi familia" $(C, 6)$.

\section{REFERENCES}

Armistead, Samuel G. \& Silverman, Joseph H. (Eds.). (1971). The Judeo-Spanish Ballad Chapbooks of Yacob Abraham Yoná. Berkeley: University of California Press.

Armistead, Samuel G. \& Silverman, Joseph H. (Eds.). (1979). Tres calas en el romancero sefardí: Rodas, Jerusalén, Estados Unidos. Madrid: Castalia.

Barnett, Neil. (1974). Introduction. In Leon Sciaky, Farewell to Salonica: City at the Crossroads (pp. 1-9). London: Haus Books.

Bornstein-Makovetsky, Leah. (2019). Protestant Missionaries to the Jewish Communities of Istanbul, Salonika, and Izmir. Istanbul: Libra Kitap.

Bunis, David. (1999). Voices from Jewish Salonika. Jerusalem \& Thessaloniki: Misgav Yerushalayim.

Bürki, Yvette. (2010). The Ottoman Press at the Dawn of the Twentieth Century, European Judaism, 43(2), 102-116.

Díaz-Mas, Paloma (Ed.). (1994). Poesía oral sefardí. Ferrol: Sociedad de Cultura Valle-Inclán.

Dorn Sezgin, Paméla. (2005). Jewish Women in the Ottoman Empire. In Zion Zohar (Ed.), Sephardic and Mizrahi Jewry from the Golden Age of Spain to Modern Times (pp. 216-235). New York: New York University Press. 
Garnett, Lucy M. J. (1891). The Women of Turkey and Their Folk-lore. London: David Nutt.

Gaon, Moshe David. (1965). A Bibliography of the Judeo-Spanish (Ladino) Press. Jerusalem: Ben-Zvi Institute, The Hebrew University [in Hebrew].

Hadar, Gila. (2006). Carmen in Salonika - Gender, Family and Tension among Jewish Women Tobacco Workers. Pe'amim, 107, 5-37 [in Hebrew].

Hadar, Gila. (2007). Jewish Tobacco Workers in Salonika: Gender and Family in the Context of Social Life and Ethnic Strife. In Amila Butorovic \& Irvin Cemil Schick (Eds.), Women in the Ottoman Balkans: Gender, Culture and History (pp. 127-152). New York: Tauris.

Hadar, Gila. (2015). Reyna Cohen, Writer and Mystic Jewish Woman from Salonika. In Eliezer Papo, Haim Weiss, Yaakov Bentolila \& Yuval Harari (Eds.), Dameta le-Tamar: Researches Dedicated to Tamar Alexander (pp. 149-166). Beer-Sheva: Ben-Gurion University Press [in Hebrew].

Juhasz, Esther. (1990). Textiles for the Home and Synagogue. In Esther Juhasz (Ed.), Sephardi Jews in the Ottoman Empire: Aspects of Material Culture (pp. 65-119). Jerusalem: The Israel Museum.

Mazower, Mark. (2004). Salonica City of Ghosts: Christians, Muslims and Jews 1430-1950. London: Harper Perennial.

Molho, Rena. (1993). Education in the Jewish Community of Thessaloniki in the Beginning of the Twentieth Century, Balkan Studies, 34, 259-269.

Molho, Rena. (2005): Salonica and Istanbul: Social, Political and Cultural Aspects of Jewish Life. Istanbul: The Isis Press.

Pomeroy, Hilary. (1999). The Judeo-Spanish Ballad Tradition of Salonica. In Raphael Gatenio (Ed.), Judeo Espaniol: The Evolution of a Culture (pp. 37-47). Thessaloniki: Ets Ahaim Foundation.

Pomeroy, Hilary. (2002). "Desde la Cuna hasta la Tumba" - "From the Cradle to the Grave" Life-Cycle Customs and Songs of the Sephardim. In Raphael Gatenio (Ed.), Judeo Espaniol: A Jewish Language in Search of its People (pp. 63-74). Thessaloniki: Ets Ahaim Foundation.

Pomeroy, Hilary. (2008). Evolution and Transformation in the Sephardic Ballad Tradition. In Rena Molho (Ed.), Judeo Espagnol: La vida social y cultural en Salonica a traves los textos judeo-espagnoles (pp. 189-199). Thessaloniki: Ets Ahaim Foundation.

Refael, Shmuel. (2002). The Longing for Zion in Judeo-Spanish (Ladino) Poetry. In Minna Rozen (Ed.), The Last Ottoman Century and Beyond: The Jews in Turkey and the Balkans 1808-1945, II, (pp. 207-218). Tel-Aviv: Goldstein-Goren Diaspora Research Centre.

Rodrigue, Aron. 1993. Images of Sephardi and Eastern Jewries in Transition: The Teachers of the Alliance Israélite Universelle, 1860-1939. Seattle \& London: University of Washington Press.

Romero, Elena. (1992). La creación literaria en lengua sefardí. Madrid: Mapfre.

Romero, Elena. (2008). Entre dos (o más) fuegos: fuentes poéticas para la historia de los sefardíes de los Balcanes. Madrid: Consejo Superior de Investigaciones Superiores.

Russo-Katz, Miriam. (1990). Jewelry. In Esther Juhasz (Ed.), Sephardi Jews in the Ottoman Empire: Aspects of Material Culture (pp. 172-195). Jerusalem: The Israel Museum.

Sleeman, Margaret Grace. (1991). An Edition and Study of Judeo-Spanish Ballads Collected in Britain [Ph.D. Thesis, University of Aberdeen]. 
Stavroulakis, Nicholas. (1988). Sephardi and Romaniot Jewish Costumes in Greece and Turkey. Athens: The Jewish Museum of Greece and The Friends of the Jewish Museum of Greece.

Weich-Shahak, Susana (Ed.). (2012). El Ciclo de la Vida en el Repertorio Musical de las Comunidades de Oriente. Madrid: Editorial Alpuerto. 